\title{
PENGEMBANGAN LEMBAR KEGIATAN SISWA BERBASIS GUIDED DISCOVERY PADA MATERI BANGUN RUANG SISI DATAR SISWA KELAS VIII SMP NEGERI 14 SURAKARTA
}

\author{
Kartika Maharani ${ }^{1}$, Dyah Ratri ${ }^{2}$, Henny Ekana ${ }^{3}$ \\ ${ }^{1,2,3}$ FKIP Matematika Universitas Sebelas Maret Surakarta
}

\begin{abstract}
The research aims to describe the development procedure of Student Activity Sheets (SAS) using Guided Discovery and to obtain a valid, attractive, efficient, and effective Student Activity Sheets to Improve Students' Learning Outcomes. The research population is all of the eighth grade students in Junior High School 14 Surakarta. Two classes used as the samples are VIII A and VIII B through cluster random sampling. The type of this research is a Research and Development $(\mathrm{R}$ $\&$ D). The development procedure of this research is based on ADDIE (Analyse, Design, Development, Implementation, and Evaluation) Development Model. The scoring result from the material experts reach the average score of 3.36 in the level 'good' and the scoring result from the design experts reach the average score of 3.25 in the level 'good'. Therefore, the data shows that the SAS is considered to be valid. The result from the student questionnaire responses reach the average score of 3.56 in the level 'very good'. Therefore, it can be concluded that the SAS is attractive. Meanwhile, the scoring result from the teacher questionnaire responses reach the average score of 3.4 in the level 'good'. Therefore, it can bee seen that the SAS is considered to be efficient. To see the effectiveness of SAS conducted t-test and from the average test result with $t$ test, $t=1,9881$ is a member of $D K=\{t \mid t>1,645\}$. This means that the value of the students' learning outcomes in the experimental class is better than the control class, so that it can be concluded that the SAS effectively improves student learning outcomes. From this result, it can be concluded that Student Activity Sheets of Polyhedron Material using Guided Discovery is considered to be valid, attractive, efficient, and effective.
\end{abstract}

Keyword: pengembangan, LKS, penemuan terbimbing, geometri

\section{PENDAHULUAN}

Kurikulum 2013 merupakan salah satu kurikulum yang diterapkan di Indonesia dalam proses pembelajaran pada jenjang pendidikan dasar dan menengah. Kurikulum 2013 dikembangkan dengan penyempurnaan pola pembelajaran yang berpusat pada guru menjadi berpusat pada peserta didik, pola pembelajaran satu arah menjadi interaktif, pola pembelajaran pasif menjadi aktif-mencari dan pembelajaran kritis, dan pola belajar sendiri menjadi belajar kelompok (Permendikbud No. 70 Tahun 2013). Dalam Permendikbud No. 81A tahun 2013 tentang implementasi kurikulum 2013 dijelaskan bahwa untuk mencapai kualitas yang telah dirancang dalam dokumen kurikulum 2013, kegiatan pembelajaran perlu menggunakan prinsip yang: (1) berpusat pada peserta didik, (2) mengembangkan kreativitas peserta didik, (3) menciptakan kondisi menyenangkan dan menantang, (4) bermuatan nilai, etika, estetika, logika, dan kinestetika, dan (5) menyediakan pengalaman belajar yang beragam melalui penerapan berbagai strategi dan metode pembelajaran yang menyenangkan, kontekstual, efektif, efisien, dan bermakna. 
Pembelajaran menggunakan kurikulum 2013 mendorong peserta didik untuk terlibat secara aktif dalam menemukan suatu konsep dan mentransformasikan informasi kompleks, mengecek informasi baru dengan yang sudah ada dalam ingatannya, dan melakukan pengembangan menjadi informasi atau kemampuan yang sesuai dengan lingkungan dan jaman tempat dan waktu ia hidup melalui bimbingan guru. Kurikulum 2013 menganut pandangan dasar bahwa pengetahuan tidak dapat dipindahkan begitu saja dari guru ke peserta didik. Peserta didik adalah subjek yang memiliki kemampuan untuk secara aktif mencari, mengolah, mengkonstruksi, dan menggunakan pengetahuan. Untuk itu pembelajaran harus berkenaan dengan kesempatan yang diberikan kepada peserta didik untuk membangun pengetahuan dalam proses kognitifnya.

Proses pembelajaran dengan kurikulum 2013 telah diterapkan pada jenjang Sekolah Dasar (SD), Sekolah Menengah Pertama (SMP), dan Sekolah Menengah Atas (SMA). Salah satu Sekolah Menengah Pertama (SMP) di Surakarta yang sudah menerapkan kurikulum 2013 dalam proses pembelajarannya adalah SMP Negeri 14 Surakarta. Hasil belajar siswa pada materi matematika di SMP Negeri 14 Surakarta tergolong masih rendah. Hal ini dibuktikan dari data hasil Ujian Nasional (UN) matematika dalam aplikasi PAMER UN 2016/2017 dengan jumlah peserta UN sebanyak 206, siswa pada mata pelajaran matematika berada pada kategori $\mathrm{C}$ dengan rata-rata 58,99 dan distribusi nilai matematika terbanyak pada rentang nilai antara 40,0 - 5,0 yaitu sejumlah 88 siswa, atau apabila dipersentasekan menjadi 42,72\%. Hasil tersebut mengindikasikan bahwa mata pelajaran matematika memiliki hasil belajar yang masih rendah.

Salah satu materi yang diujikan dalam UN adalah materi bangun ruang sisi datar. Materi ini diajarkan di kelas VIII semester genap. Materi bangun ruang sisi datar dominan memuat pengayaan dalam memahami konsep sehingga dalam mempelajari materi bangun ruang sisi datar memerlukan keterlibatan siswa secara utuh, memerlukan penyelidikan, membutuhkan bimbingan untuk memahami dan memunculkan ide-ide dari masalah matematik, dan juga hal-hal lain yang berkaitan dengan pemecahan masalah (Rizki dan Syutaridho, 2014). Hasil UN SMP/MTs tahun pelajaran 2015/2016 dan 2016/2017 di SMP Negeri 14 Surakarta yang diperoleh dari aplikasi PAMER UN menunjukkan daya serap siswa pada indikator terkait materi bangun ruang sisi datar rendah dibandingkan dengan persentase yang diperoleh pada tingkat Kota/Kabupaten Surakarta, Provinsi Jawa Tengah, dan pada tingkat Nasional. dalam hal menentukan luas permukaan bangun ruang sisi datar daya serap siswa tingkat sekolah hanya 36, 24\%, lebih rendah daripada daya serap siswa pada tingkat Kota/Kab yaitu 47,43\%. Selain itu dalam 
hal menentukan unsur-unsur bangun ruang sisi datar daya serap siswa tingkat sekolah hanya 51, 46\%, lebih rendah daripada daya serap siswa pada tingkat Kota/Kab yaitu 56, $42 \%$ sedangkan untuk menentukan volume prisma daya serap siswa tingkat sekolah hanya 53, 40\%, lebih rendah daripada daya serap siswa pada tingkat Kota/Kab yaitu 56, $23 \%$.

Untuk melihat kemungkinan penyebab rendahnya hasil belajar siswa di SMP Negeri 14 Surakarta, maka peneliti melakukan observasi pada bulan Januari 2018 selama proses pembelajaran di kelas VIII dan wawancara dengan guru mata pelajaran matematika kelas VIII. Berdasarkan observasi, walaupun sekolah sudah menerapkan kurikulum 2013 namun dalam praktik pengajaranya masih belum sepenuhnya mencerminkan kurikulum 2013 dan masih memiliki keterbatasan pengadaan buku pelajaran. Dalam proses pembelajaran, guru masih menggunakan model pembelajaran langsung, alasan menggunakan model pembelajaran langsung menurut salah satu guru karena lebih efisien untuk mengajarkan materi dengan kondisi mininya buku pelajaran matematika sehingga materi pelajaran matematika harus disampaikan secara langsung oleh guru. Dalam menerapkan model pembelajaran langsung, beberapa waktu belakangan guru juga menggunakan bantuan LCD dan proyektor untuk mengajar karena menurut guru tersebut jika mengajar dengan menulis di papan tulis terus menerus membuat guru lelah, akan lebih praktis jika di terangkan melalui proyektor dan ada variasi penyampaian materi di kelas. Model pembelajaran yang digunakan guru kurang memberi ruang untuk siswa aktif dan mencoba terlebih dahulu.

Selain faktor model pembelajaran yang digunakan, salah satu penyebab prestasi belajar siswa rendah karena keterbatasan bahan ajar, siswa hanya mengandalkan catatan saja. Kurangnya bahan ajar untuk siswa sebenarnya dapat diatasi oleh guru dengan membuat bahan ajar sendiri sehingga dapat digunakan siswa dalam proses pembelajaran. Namun saat peneliti melakukan wawancara dengan guru mata pelajaran matematika, beliau mengatakan bahwa tidak sempat membuat bahan ajar untuk digunakan dalam proses pembelajaran karena keterbatasan waktu dan tugas guru yang sudah banyak, beliau hanya menyampaikan materi melalui LCD proyektor dan apabila ada siswa yang hendak meminta filenya untuk dicopy diperbolehkan. Untuk memperlancar proses pembelajaran harus didukung dengan ketersediaan yang cukup terhadap bahan ajar yang sesuai dengan kurikulum 2013. Menurut pendapat dari Depdiknas (2008: 2), bahan ajar merupakan bagian penting dalam pelaksanaan pendidikan di sekolah. Melalui bahan ajar guru akan lebih mudah dalam melaksanakan pembelajaran dan siswa akan lebih terbantu dan mudah dalam belajar. Ketika bahan ajar dibuat sendiri oleh pendidik yang dalam hal ini adalah 
guru, pembelajaran akan menjadi lebih menarik dan mengesankan bagi siswa karena guru lebih mengetahui karakteristik siswa.

Dalam Permendikbud Nomor 65 Tahun 2013 mengenai Standar Proses, proses pembelajaran pada Kurikulum 2013 ditekankan pada pendekatan scientific (ilmiah) dengan pembelajaran berbasis penemuan/penyelidikan (discovery/ inquiry learning), berbasis masalah (problem based learning) dan atau berbasis pemecahan masalah (project based learning). Pelaksanaan pembelajaran pada kegiatan inti dapat menggunakan salah satu model yang telah disebutkan disesuaikan dengan karakteristik peserta didik dan karakteristik kompetensi mata pelajaran. Model pembelajaran penemuan (discovery learning) merupakan salah satu model pembelajaran yang inovatif dan merupakann suatu model pembelajaran berdasarkan pandangan konstruktivisme. Konstruktivisme adalah teori pembelajaran yang menyatakan bahwa perkembangan kognitif merupakan suatu proses dimana siswa secara aktif membangun sistem arti dan pemahaman terhadap realita melalui pengalaman serta interaksi mereka (Trianto, 2011). Pembelajaran penemuan menurut Prasetyo dkk (dalam Suprihatiningrum, 2013: 245) dibedakan menjadi dua, yaitu pembelajaran penemuan bebas (free discovery learning) atau sering disebut open ended discovery dan pembelajaran penemuan terbimbing (guided discovery learning). Bagi siswa yang masih duduk di bangku sekolah menengah ke bawah, penemuan yang dilakukan masih memerlukan bantuan dari guru sehingga model penemuan ini disebut model penemuan terbimbing (guided discovery learning). Dengan belajar penemuan terbimbing, siswa bisa belajar berpikir lebih sistematis dan memecahkan masalah yang dihadapi.

Untuk mendukung model pembelajaran penemuan terbimbing (guided discovery learning) agar dapat diterapkan dengan baik dalam proses pembelajaran di kelas diperlukan bahan ajar berupa Lembar Kegiatan Siswa (LKS). Menurut Depdiknas (2008: 13) lembar kegiatan siswa adalah lembaran-lembaran berisi tugas-tugas yang dilengkapi dengan petunjuk atau langkah-langkah yang harus dikerjakan oleh siswa. Sedangkan Prastowo (2012: 204) mengemukakan bahwa LKS merupakan suatu bahan ajar cetak berupa lembar-lembar kertas yang berisi materi, ringkasan, dan petunjuk-petunjuk pelaksanaan tugas pembelajaran yang harus dikerjakan oleh peserta didik, yang mengacu pada kompetensi dasar yang harus dicapai. Sebagai bahan ajar, LKS dapat meminimalkan peran pendidik namun mengaktifkan peserta didik dan mempermudah peserta didik untuk memahami materi yang diberikan (Prastowo, 2013: 205). Di dalam LKS terdapat kegiatan yang dapat menuntun siswa untuk terlibat secara aktif dalam proses menemukan dan memahami suatu konsep materi yang dipelajari. Menurut Depdiknas (2008), LKS 
berfungsi untuk membantu siswa menemukan konsep dan menerapkan konsep yang telah ditemukan.

Berdasarkan masalah-masalah yang telah dikemukakan di atas, maka peneliti tertarik untuk mengembangkan Lembar Kegiatan Siswa (LKS) yang diharapkan dapat mengatasi minimnya bahan ajar pelajaran matematika yang digunakan di kelas dan untuk meningkatkan hasil belajar siswa. Oleh karena itu penelitian ini diberi judul "Pengembangan Lembar Kegiatan Siswa (LKS) berbasis Penemuan Terbimbing (Guided Discovery) untuk Meningkatkan Hasil Belajar pada Materi Bangun Ruang Sisi Datar untuk Siswa Kelas VIII SMP Negeri 14 Surakarta". Adapun rumusan masalah dalam penelitian ini adalah: 1) Bagaimana prosedur pengembangan LKS materi Bangun Ruang Sisi Datar berbasis penemuan terbimbing (Guided Discovery)?, 2) Apakah LKS materi Bangun Ruang Sisi Datar berbasis penemuan terbimbing (Guided Discovery) valid digunakan dalam proses pembelajaran?, 3) Apakah LKS materi Bangun Ruang Sisi Datar berbasis penemuan terbimbing (Guided Discovery) menarik digunakan dalam proses pembelajaran?, 4) Apakah LKS materi Bangun Ruang Sisi Datar berbasis penemuan terbimbing (Guided Discovery) efisien digunakan dalam proses pembelajaran?, dan 5) Apakah LKS materi Bangun Ruang Sisi Datar berbasis penemuan terbimbing (Guided Discovery) efektif?

Penelitian ini bertujuan untuk mendeskripsikan prosedur pengembangan LKS materi Bangun Ruang Sisi Datar d berbasis penemuan terbimbing (Guided Discovery) dan untuk memperoleh LKS materi bangun ruang sisi datar berbasis penemuan terbimbing (Guided Discovery) yang valid, menarik, efisien, dan efektif meningkatkan hasil belajar siswa.

\section{METODE PENELITIAN}

Jenis penelitian yang digunakan adalah penelitian pengembangan. Menurut Sugiyono (2013), metode penelitian dan pengembangan (research and development) adalah metode penelitian yang digunakan untuk menghasilkan produk tertentu, dan menguji keefektifan produk tersebut. Penelitian pengembangan adalah upaya untuk mengembangkan dan menghasilkan suatu produk berupa materi, media, alat, dan atau strategi pembelajaran, digunakan untuk mengatasi pembelajaran di kelas/laboratorium, dan bukan untuk menguji teori (Tegeh, 2014). Prosedur penelitian pengembangan ini mengacu pada model ADDIE (Analyze, Design, Development, Implementation, Evaluation). Pemilihan model ini didasari atas pertimbangan bahwa model ini dikembangkan secara sistematis dan berpijak pada landasan teoritis desain pembelajaran 
(Tegeh, dkk., 2014: 41). Model ini disusun secara terprogram dengan urutan-urutan kegiatan yang sistematis dalam upaya pemecahan masalah belajar yang berkaitan dengan sumber belajar yang sesuai dengan kebutuhan dan karakteristik pebelajar (Tegeh, dkk., 2014: 44). Selain itu, model ini memiliki lima langkah atau tahapan yang mudah dipahami dan diimplementasikan untuk mengembangkan produk pengembangan seperti buku ajar, modul pembelajaran, video pembelajaran, multimedia dan lain sebagainya.

Lebih lanjut Tegeh, Jampel, dan Pudjawan (2014) mengatakan bahwa model ADDIE memberikan peluang untuk melakukan evaluasi terhadap aktivitas pengembangan pada setiap tahap. Hal ini berdampak positif terhadap kualitas produk pengembangan. Dampak positif yang ditimbulkan dengan adanya evaluasi pada setiap tahap adalah meminimalisir tingkat kesalahan atau kekurangan produk pada tahap akhir model ini. Tahap analisis (analyze) meliputi analisis kompetensi yang dituntut kepada peserta didik, analisis karakteristik peserta didik, dan analisis materi sesuai dengan tuntutan kompetensi. Tahap perancangan (design) difokuskan pada tiga kegiatan, yaitu pemilihan materi sesuai dengan karakteristik peserta didik dan tuntutan kompetensi, strategi pembelajaran yang diterapkan dan bentuk serta metode asesmen dan evaluasi yang digunakan. Tahap ketiga adalah kegiatan pengembangan (development) yang pada intinya adalah kegiatan menerjemahkan spesifikasi desain ke dalam bentuk fisik, sehingga kegiatan ini menghasilkan prototype produk pengembangan.

Tahap keempat adalah implementasi (implementation), hasil pengembangan diterapkan dalam pembelajaran untuk mengetahui pengaruhnya terhadap kualitas pembelajaran yang meliputi keefektifan, kemenarikan, dan efisiensi pembelajaran. Prototype produk pengembangan perlu diujicobakan secara riil di lapangan untuk memperoleh gambaran tentang tingkat keefektifan, kemenarikan dan efisiensi pembelajaran. Tahap terakhir adalah evaluasi (evaluation), evaluasi dapat dilakukan dengan cara membandingkan antara hasil pembelajaran yang telah dicapai oleh siswa dengan tujuan pembelajaran yang telah dirumuskan sebelumnya. Pada tahap terakhir ini dilakukan evaluasi yang meliputi evaluasi formatif dan evaluasi sumatif. Evaluasi formatif dilakukan untuk mengumpulkan data setiap tahapan yang digunakan untuk penyempurnaan dan evaluasi sumatif dilakukan pada akhir program pembelajaran untuk mengetahui pengaruhnya terhadap hasil belajar peserta didik (keefektifan produk yang dikembangkan) dan kualitas pembelajaran secara luas.

Populasi dari penelitian ini adalah seluruh siswa SMP Negeri 14 Surakarta kelas VIII tahun ajaran 2017/2018 yang terdiri dari 7 kelas. Sampel penelitian ini adalah dua kelas dari 7 kelas yang ada di SMP Negeri 14 Surakarta tahun ajaran 2017/2018. 
Pengambilan sampel dilakukan dengan teknik cluster random sampling. Pada teknik cluster random sampling. Hasilnya diperoleh kelas VIII A yang berfungsi sebagai kelas eksperimen terdiri dari 30 siswa dan kelas VIII B yang berfungsi sebagai kelas kontrol terdiri dari 31 siswa.

Data yang diperoleh dalam penelitian pengembangan ini adalah data kualitatif dan kuantitatif. Data kualitatif diperoleh dari hasil review ahli materi dan ahli desain melalui angket, serta hasil wawancara yang dilakukan oleh peneliti terhadap guru dan siswa. Data kualitatif digunakan sebagai pertimbangan dalam melakukan pengembangan LKS dan dalam melakukan revisi LKS. Data kuantitatif diperoleh dari skor angket dan hasil tes siswa dalam uji coba. Data kuantitatif berupa angka-angka yang kemudian direkapitulasikan sehingga didapatkan tingkat kelayakan LKS yang dikembangkan.

Sumber data dalam penelitian ini terdiri dari ahli materi, ahli desain, guru, siswa kelas VIII A dan VIII B SMP Negeri 14 Surakarta Tahun Ajaran 2017/2018 sebagai kelas ujicoba LKS, siswa kelas VIII A SMP Negeri 16 Surakarta Tahun Ajaran 2017/2018 sebagai kelas ujicoba instrumen tes, aplikasi Pamer UN. Ahli materi yaitu tiga orang Dosen Pendidikan Matematika FKIP UNS, dua orang ahli desain yang meliputi satu orang dosen komunikasi visual UNS dan satu orang dosen pengampu visualisasi 2D STMIK AMIKOM Purwokerto. Pengumpulan data dalam penelitian dilakukan dengan beberapa teknik yaitu wawancara, angket, tes hasil belajar, dan dokumentasi.

Dalam upaya untuk mendapatkan LKS yang valid digunakan angket penilaian LKS untuk ahli materi dan ahli desain, untuk menilai kemenarikan digunakan angket respon siswa, keefisiensian digunakan angket respon guru. Angket yang diberikan menggunakan skala Likert 1 sampai 4, dan untuk menilai keefektifan digunakan tes hasil belajar. Adapun skor angket tersebut kemudian dikonversikan menggunakan pedoman konversi perhitungan skor angket (diadopsi dari Widoyoko, 2009: 238) pada Tabel 1 berikut:

Tabel 1. Konversi Data Kuantitaif ke Data Kualitatif

\begin{tabular}{cc}
\hline Rentang skor $(i)$ & Kriteria \\
\hline$-x>x_{i}+1,8 s b_{i}$ & Sangat Baik \\
\hline$x_{i}+0,6 s b_{i}<\bar{x} \leq x_{i}+1,8 s b_{i}$ & Baik \\
\hline$x_{i}-0,6 s b_{i}<\bar{x} \leq x_{i}+0,6 s b_{i}$ & Cukup \\
\hline$x_{i}-1,8 s b_{i}<\bar{x} \leq x_{i}-0,6 s b_{i}$ & Kurang \\
\hline$x \leq x_{i}-1,8 s b_{i}$ & Sangat Kurang \\
\hline
\end{tabular}

Keterangan:

$x_{i} \quad:$ rerata ideal $=\frac{1}{2} \mathrm{x}($ skor maksimal ideal + skor minimal ideal $)$

$s b_{i} \quad:$ simpangan baku ideal $=\frac{1}{6} \mathrm{x}($ skor maksimal ideal - skor minimal ideal $)$ 
Dalam penelitian pengembangan LKS ini, skor maksimal ideal adalah 4 dan skor minimal ideal adalah 1. maka didapat pedoman konversi data kuantitatif menjadi kualitatif untuk penelitian ini pada Tabel 2 berikut:

Tabel 2. Pedoman Konversi Data Kuantitatif menjadi Kualitatif

\begin{tabular}{cc}
\hline Interval Skor & Kriteria \\
\hline $\bar{x}>3,4$ & Sangat baik \\
\hline $2,8<\bar{x} \leq 3,4$ & Baik \\
\hline $2,2<\bar{x} \leq 2,8$ & Cukup \\
\hline $1,6<\bar{x} \leq 2,2$ & Kurang \\
\hline $\bar{x} \leq 1,6$ & Sangat kurang \\
\hline
\end{tabular}

LKS dinyatakan valid apabila skor penilaian untuk ahli materi dan ahli desain minimal berada pada kategori cukup. Untuk menyatakan kemenarikan dan keefisiensian, angket respon siswa dan guru minimal berada pada kategori cukup. LKS efektif dalam meningkatkan nilai hasil belajar siswa jika uji hipotesis mengenai rerata menyimpulkan bahwa nilai hasil belajar siswa kelas eksperimen lebih baik daripada kelas kontrol dengan hasil uji t menyatakan $t_{\text {hitung }}>t_{\text {tabel }}$.

\section{HASIL DAN PEMBAHASAN}

Peneliti mengembangkan LKS materi bangun ruang sisi datar dengan model penemuan terbimbing (guided discovery) menggunakan model pengembangan ADDIE (Analyze, Design, Development, Implementation, Evaluation). Pada tahap pertama yaitu analisis (analyze) meliputi analisis pendahuluan, analisis kompetensi yang dituntut kepada peserta didik, analisis karakteristik peserta didik, dan analisis materi sesuai dengan tuntutan kompetensi. Pada tahap ini diperoleh kompetensi yang dituntut kepada peserta didik berdasarkan silabus matematika yaitu kompetensi dasar 3.9 membedakan dan menentukan luas permukaan dan volume bangun ruang sisi datar dan 4.9 menyelesaikan masalah yang berkaitan dengan luas permukaan dan volume bangun ruang sisi datar. Karakteristik peseta didik yang duduk di bangku SMP mulai berada pada pada akhir tahap operasional konkrit memasuki tahap operasional formal, dimana siswa pada tahap ini masih membutuhkan benda-benda nyata untuk dapat memahami materi bangun ruang sisi datar, akan tetapi perlahan siswa diberikan gambar-gambar dan diajarkan agar dapat berpikir abstrak. Materi pokok yang akan disampaikan di dalam LKS adalah pengertian, jaring-jaring, luas permukaan, dan volume bangun ruang sisi datar. Materi yang dipilih telah disesuaikan dengan kompetensi, karakteristik siswa, waktu dan jadwal 
di sekolah serta dapat disampaikan dengan model pembelajaran penemuan terbimbing (guided discovery).

Tahap kedua, yaitu perancangan (design) dilakukan pemilihan format LKS, desain awal LKS, dan penyusunan instrumen penelitian. Pada tahap ini dibuat peta kebutuhan LKS untuk mengetahui jumlah LKS yang harus ditulis dan urutan LKS-nya juga dapat dilihat. Pada LKS yang dikembangkan dilengkapi dengan popup jaring-jaring kubus, balok, prisma, dan limas, yang dapat dipergunakan secara individu oleh siswa. Untuk mempermudah perhitungan dalam menilai LKS yang dikembangkan, dibuat beberapa aspek penilaian dan format penilaian menggunakan skala likert dengan 4 alternatif jawaban. Selain itu dirancang evaluasi yang akan digunakan untuk menentukan keefektifan LKS yang dikembangkan yaitu dengan membuat tes hasil belajar berupa soalsoal objektif sebanyak 35 butir soal dengan 4 alternatif jawaban, dengan skor 1 untuk jawaban benar dan skor 0 untuk jawaban salah.

Pada tahap ketiga yaitu tahap pengembangan (develop), dibuat RPP untuk membantu pelaksanaan pembelajaran dengan LKS yang dikembangkan yang terlebih dahulu dikonsultasikan dengan validator kemudian direvisi sesuai saran. Selanjutnya dibuat instrumen penelitian dan divalidasikan kepada validator sebelum digunakan dalam penelitian. Setelah instrumen penelitian siap digunakan kemudian tes hasil belajar yang telah disesuaikan dengan kisi-kisi dan dibuat kunci jawabanya kemudian divalidasikan kepada validator. Pada tahap ini, juga dibuat draft LKS berdasarkan desain awal pada tahap sebelumnya, kemudian divalidasikan kepada tim ahli, direvisi, dan dinilai kevalidannya. LKS yang telah dikembangkan direvisi beberapa kali karena masih terdapat kesalahan pada bagian materi, jenis dan ukuran huruf yang digunakan, tampilan cover LKS, dan masih terdapat beberapa kesalahan tulisan di dalam LKS.

Setelah selesai direvisi kemudian LKS diberi penilaian oleh ahli materi dan ahli desain. Dari hasil validasi ahli materi terhadap LKS yang dikembangkan sudah memenuhi aspek didaktik, aspek kualitas materi dalam LKS, aspek model pembelajaran penemuan terbimbing, dan hasil validasi ahli desain terhadap LKS yang dikembangkan sudah memenuhi aspek konstruksi, dan aspek teknis, hasil validasi ahli materi dan ahli desain untuk menilai kevalidan LKS. Dalam penilaian kevalidan LKS oleh ahli materi dan ahli desain, LKS dinyatakan valid digunakan dengan revisi berdasarkan saran yang diberikan. Berdasarkan penilaian dari ahli materi yang memberikan rata-rata skor untuk seluruh aspek sebesar 3,36 dengan kriteria baik, dan penilaian dari ahli desain yang memberikan rata-rata skor untuk seluruh aspek sebesar 3, 25 dengan kriteria baik. 
Tahap keempat adalah implementasi (implementation) merupakan tahap penggunakan LKS untuk di uji coba lapangan. Uji coba lapangan dilakukan untuk memperoleh masukan langsung dari siswa dan guru terhadap LKS yang telah dikembangkan dan digunakan selama proses pembelajaran materi bangun ruang sisi datar. LKS diuji cobakan kepada kelas eksperimen yaitu kelas VIII A dengan jumlah siswa sebanyak 30 orang. Pembelajaran dengan menggunakan LKS berjalan selama 6 kali pertemuan dan diakhiri dengan pertemuan ke-7 untuk ulangan materi bangun ruang sisi datar. Untuk kelas kontrol dengan jumlah siswa sebanyak 31 orang diajarkan materi bangun ruang sisi datar selama 7 kali pertemuan dan diakhiri dengan pertemuan ke-8 untuk ulangan materi bangun ruang sisi datar.

Dari hasil penelitian di kelas eksperimen diketahui bahwa LKS menarik dan mudah dipahami karena adanya gambar dan pop up/replika bangun ruang sisi datar, hal tersebut dapat diketahui saat proses pembelajaran dan dibuktikan dengan hasil komentar siswa pada angket respon siswa. Hal ini sejalan dengan tingkat perkembangan kognitif Jean Piaget yang menyatakan bahwa siswa SMP berada pada akhir tahap operasional konkrit memasuki tahap operasional formal, dimana siswa pada tahap ini masih membutuhkan benda-benda nyata untuk dapat memahami materi bangun ruang sisi datar, akan tetapi perlahan siswa diberikan gambar-gambar dan diajarkan agar dapat berpikir abstrak. Selain itu, adanya LKS berbasis penemuan terbimbing, membuat siswa aktif di kelas menemukan melalui percobaan/kegiatan penemuan yang dilakukan secara individu maupun berkelompok. Tentu saja, hal ini sesuai dengan pendapat dari Prasetyo dkk (dalam Suprihatiningrum, 2013: 245), dengan pembelajaran penemuan terbimbing akan dapat memberikan pengalaman langsung kepada siswa sehingga pembelajaran akan lebih bermakna yang diharapkan dapat memperbaiki hasil belajar siswa sebelumnya yang kurang baik menjadi lebih baik.

Pada tahap ini dilakukan uji kemenarikan dan keefisiensian LKS. Uji kemenarikan dilakukan dengan memberikan angket respon siswa setelah menggunakan LKS yang dikembangkan dan uji keefisiensian dengan memberikan angket respon guru setelah pembelajaran dengan LKS selesai dilaksanakan. LKS dari segi kemenarikan tergolong menarik digunakan dalam pembelajaran karena didasarkan pada hasil penilaian angket respon siswa terhadap LKS dengan rata-rata skor untuk seluruh aspek sebesar 3,56 dengan kriteria sangat baik. Dilihat dari segi keefisiensian, LKS tergolong efisien dengan skor 3,4 dan mendapat kriteria baik serta didukung dengan hasil respon positif guru terhadap LKS yang dikembangkan. 
Tahap terakhir dalam proses pengembangan LKS yaitu evaluasi (evaluation). Evaluasi yang digunakan adalah evaluasi formatif dan sumatif. Evaluasi formatif dilakukan untuk mengumpulkan data setiap tahapan yang digunakan untuk penyempurnaan dan evaluasi sumatif dilakukan di akhir pembelajaran materi bangun ruang sisi datar. Evaluasi sumatif digunakan untuk menguji keefektifan LKS yang dikembangkan. Apabila dilihat dari segi keefektifan, hasil uji rerata dengan uji t, diperoleh $\mathrm{t}_{\text {hitung }}=1,9881>\mathrm{t}_{\text {tabel }}=1,645$, hal ini berarti nilai hasil belajar siswa kelas eksperimen lebih baik daripada kelas kontrol, sehingga LKS efektif dalam meningkatkan hasil belajar siswa.

\section{SIMPULAN DAN SARAN}

Dari penilaian para ahli dan ujicoba lapangan diperoleh bahwa LKS guided discovery yang dikembangkan dengan model ADDIE: (1) LKS valid berdasarkan penilaian kevalidan oleh ahli materi dan ahli desain dengan skor penilaian kevalidan LKS sebesar 3,36 dan 3, 25; (2) LKS menarik berdasarkan penilain dari angket respon siswa dengan skor rata-rata keseluruhan aspek sebesar 3, 56 dan mendapat respon positif siswa pada kolom komentar angket; (3) LKS efisien digunakan dalam pembelajaran berdasarkan penilain dari angket respon guru dengan skor sebesar 3, 4 dan mendapat kriteria baik serta didukung dengan respon positif guru terhadap LKS yang dikembangkan; dan (4) LKS efektif dalam meningkatkan hasil belajar siswa pada materi bangun ruang sisi datar berdasarkan uji $\mathrm{t}$ satu sisi dengan diperolehnya hasil $\mathrm{t}_{\text {hitung }}=$ $1,9881>\mathrm{t}_{\text {tabel }}=1,645$ hal ini berarti nilai hasil belajar siswa kelas eksperimen lebih baik daripada kelas kontrol, sehingga LKS efektif dalam meningkatkan hasil belajar siswa. Dari hasil tersebut dapat disimpulkan bahwa LKS yang dikembangkan valid, menarik, efisien, dan efektif.

Berdasarkan simpulan, maka peneliti mengemukakan beberapa saran, diantaranya yaitu: (1) LKS materi bangun ruang sisi datar berbasis penemuan terbimbing (Guided Discovery) yang dikembangkan dalam penelitian ini dari segi kevalidan, kemenarikan, keefisiensian, dan keefektifan telah memenuhi kriteria baik sehingga dapat digunakan oleh peserta didik ataupun guru dalam proses pembelajaran di kelas, (2) Guru lebih aktif dalam mengembangkan media/bahan ajar yang dapat mengurangi keabstrakan matematika, khususnya pada materi geometri, (3) peneliti lain yang ingin melakukan penelitian dengan LKS ini, dapat melakukan penelitian untuk menilai pengaruh LKS terhadap kemampuan siswa lainnya/aspek tertentu lainnya, (4) pengembangan LKS materi bangun ruang sisi datar berbasis penemuan terbimbing (Guided Discovery) bisa 
digunakan dalam ujicoba yang lebih besar, misalnya menggunakan lebih banyak kelas dan sekolah dalam ujicoba lapangan, sehingga diperoleh hasil penelitian yang lebih baik.

\section{DAFTAR PUSTAKA}

Depdiknas. (2008). Panduan Pengembangan Bahan Ajar. Jakarta: Direktorat Pembinaan SMA, Dirjen Mandikdasmen, Depdiknas.

Peraturan Menteri Pendidikan dan Kebudayaan Republik Indonesia Nomor 65 Tahun 2013 Tentang Standar Proses Pendidikan Dasar dan Menengah.

Peraturan Menteri Pendidikan dan Kebudayaan Republik Indonesia Nomor 81A Tahun 2013 Tentang Implementasi Kurikulum 2013.

Prastowo. (2013). Pengembangan Bahan Ajar Tematik. Jogjakarta: Diva Press

Rizki dan Syutaridho. (2014). Efektivitas bahan ajar bangun ruang sisi datar menggunakan 5E instructional model terhadap aktivitas dan hasil belajar. Jurnal Aksioma. Vol. 3, No. 2, 1 -9

Suprihatiningrum, J. (2013). Strategi Pembelajaran Teori dan Aplikasi. Yogyakarta: ArRuzz Media.

Tegeh, I. M., Jampel, I. N., dan Pudjawan, K. (2014). Model Penelitian Pengembangan. Yogyakarta: Graha Ilmu.

Trianto. (2011). Desain Pengembangan Pembelajaran Tematik bagi Anak Usia Dini TK/R \& Anak Usia Kelas Awal SD/MI. Jakarta: Kencana.

Widoyoko, E.P. (2009). Evaluasi Program Pembelajaran. Yogyakarta: Pustaka Pelajar. 